\title{
Enrichment, risk assessment, and statistical apportionment of heavy metals in tannery-affected areas
}

\author{
Z. Ali $\cdot$ R. N. Malik $\cdot$ Z. K. Shinwari • \\ A. Qadir
}

Received: 12 June 2012/Revised: 16 June 2013/ Accepted: 5 November 2013/Published online: 27 November 2013

(C) Islamic Azad University (IAU) 2013

\begin{abstract}
Tannery-affected surface soils from 72 sampling sites from industrial area of Sialkot district, Pakistan, were collected and analyzed for nine physicochemical parameters, nine heavy metals, and four macro-nutrients. Most of the soils were poor in organic matter $(0.11-2.98 \%)$, basic in nature with $\mathrm{pH}(7.1-10.6)$ and electrical conductivity $(1.2-17.9 \mathrm{mS} /$ $\mathrm{cm})$. Mean concentration of total dissolved solids, $\mathrm{Cl}^{1-}$, alkalinity, $\mathrm{NO}_{3}{ }^{1}-\mathrm{N}$, salinity, and $\mathrm{PO}_{4}{ }^{3-}$ was $3,093 \mathrm{mg} / \mathrm{L}$, $6,587,3,929,301.3,10.3$, and $1.7 \mathrm{mg} / \mathrm{kg}$. The results showed that concentration of macro-nutrients was in the order: $\mathrm{Na}>\mathrm{Mg}>\mathrm{K}>\mathrm{Ca}$ whereas heavy metals followed the order: $\mathrm{Cr}>\mathrm{Fe}>\mathrm{Ni}>\mathrm{Mn}>\mathrm{Cu}>\mathrm{Zn}>\mathrm{Co}>\mathrm{Pb}>\mathrm{Cd}$. Factor analysis based on principal component analysis, cluster analysis, and correlation analysis identified contribution of metals from tannery effluents, agrochemicals, automobiles exhaust, and natural weathering processes. Tannery-affected soils were enriched with Cd followed by $\mathrm{Cr}, \mathrm{Pb}, \mathrm{Ni}, \mathrm{Cu}, \mathrm{Co}, \mathrm{Zn}$, and $\mathrm{Mn}$. Geo-accumulation index $\left(I_{\text {geo }}\right)$ classified the soil samples in
\end{abstract}

\section{Z. Ali}

Environmental Biology Laboratory, Department of Plant Sciences, Faculty of Biological Sciences, Quaid-i-Azam University, Islamabad 45320, Pakistan

\section{R. N. Malik ( $\square)$}

Environmental Biology and Ecotoxicology Laboratory, Department of Environmental Sciences, Faculty of Biological Sciences, Quaid-i-Azam University, Islamabad 45320, Pakistan e-mail: r_n_malik2000@yahoo.co.uk

\section{Z. K. Shinwari}

Department of Biotechnology and Bio-informatics, Faculty of Biological Sciences, Quaid-i-Azam University, Islamabad 45320, Pakistan

A. Qadir

College of Earth and Environmental Sciences, University of the Punjab, Quaid-e-Azam campus, Lahore, Pakistan unpolluted to moderately polluted categories. Metal pollution index provided better estimation of heavy metal pollution as compared to pollution load index. Ecological risk index showed high potential ecological risk associated with $\mathrm{Cd}$ and $\mathrm{Cr}$ with mean concentrations above respective average shale/ background values. The results are useful for heavy metals source identification, enrichment, risk assessment, and management of tannery-affected soils and can contribute to monitoring programs at regional levels.

Keywords Cluster analysis - Ecological risk index · Enrichment indices · Factor analysis · Geo-accumulation

\section{Introduction}

Leather industry plays a major role in economic uplift of many developing countries including Pakistan. It is associated with the generation of huge amount of liquid and solid wastes. Improper disposal of hazardous/toxic waste coupled with inadequate management has resulted in serious environmental problems in recent years. Leathermanufacturing processes such as soaking, liming/deliming, bathing, pickling, skin degreasing, tanning, and post-tanning of raw hides/skins involve chemicals such as sodium hydroxide, sodium hypochlorite, enzymes, lime, chlorides, sulfuric acid, formic acid, ammonium salts, and kerosene, etc. (Tariq et al. 2006). Among these processes, liming and tanning are the most polluting steps. Liming involves excessive use of sulfite ions while tanning entails either usage of Cr salts or plant tannins (Tariq et al. 2009).

In Pakistan, $>600$ tannery units have been reported. They are mostly centered in formally designated industrial zones of big cities such as Karachi, Kasur, Sialkot, and Peshawar (Qadir et al. 2008), and produce approximately 
36.2 million skins and 7.4 million hides with mean annual growth of 1.47 and $2.9 \%$, respectively. Unfortunately, disposal strategies for tannery solid waste and effluents are inadequate. Waste is usually dumped in dug wells, released to the water channels or open lands without prior treatment. Usually, 30-35 L of effluents is generated during chemical processing of $1 \mathrm{~kg}$ raw material and $600 \mathrm{~kg}$ solid waste for every $200 \mathrm{~kg}$ of finished leather (Qadir et al. 2008). Tannery effluents containing heavy metals have raised serious environmental concerns in recent years regarding potential risk to human health, bioaccumulation through food chain, and their impacts on ecological system.

Sialkot district is known worldwide for its leather industry, furniture, cutlery, musical, and surgical instruments. It is the third most important economic hub and second largest source of foreign exchange earner of Pakistan. There are 3,229 industrial units, including 264 tannery units which produce approximately $547-814 \mathrm{~m}^{3}$ of tannery effluents/day (Qadir et al. 2008). Over the last decades, soil contamination problems related to discharge of untreated industrial/urban effluents and wastes, indiscriminate use of chemical fertilizers/pesticides in surface soils and sewage irrigation have emerged as major environmental problems. There are serious concerns about the quality of surface soils in urban and peri-urban areas, considering the potential negative environmental influences from the tanning industry (Malik et al. 2010).

In Pakistan, few studies have been conducted so far to determine the level of heavy metals in the soils around the cities (Tariq et al. 2006; Malik et al. 2010). Different pollution indices that may help in quantification, monitoring studies, and regional management plans are also less often applied. Studies on the characteristics, spatial trends, and sources of heavy metals in soils receiving tannery effluents in particular are still needed. No study as yet has been reported from Sialkot district determining the impact of tannery effluents on the surrounding soils. There is dire need for better knowledge of heavy metal contamination in soils adjacent to tannery industries. Present study, therefore, aims at (1) determining the concentration of heavy metals, (2) ecological risk assessment, (3) correlation between metals and soil properties, (4) enrichment, and (5) source apportionment in soils of Sialkot district through pollution indices and multivariate techniques.

Pollution indices vis. enrichment factor (EF) by Dantu (2009); EF (\%) by Zonta et al. (1994) and geo-accumulation index $\left(I_{\text {geo }}\right)$ by Muller (1979); metal pollution index (MPI) by Usero et al. (2000); and ecological risk index (RI) by Hakanson (1980) and pollution load index (PLI) by Tomlinson et al. (1980) were used to compare these indices as a contribution toward building consensus on methodologies applicable to study surface soils impacted by tannery effluents. Besides, RI ecological risk was evaluated by soil quality guidelines (SQGs). Multivariate techniques, i.e., FA/PCA, cluster analysis, and correlation matrix, were applied to determine the association of selected metals with other physicochemical properties and source identification. This study not only provides information on trends, distributional pattern, fate, and apportionment of heavy metals, but also indicates the current quality of surface soils of Sialkot district. Present research was carried out between October 2009 and January 2010 at Environmental Biology Laboratory, Department of Plant Sciences, Faculty of Biological Sciences, Quaid-i-Azam University, Islamabad, Pakistan.

\section{Materials and methods}

Soil sampling and laboratory analysis

Sialkot district lies at latitude of $32^{\circ} 20^{\prime}-32^{\circ} 35^{\prime} \mathrm{N}$ and longitude of $74^{\circ} 10^{\prime}-74^{\circ} 30^{\prime} \mathrm{E}$ in northeast of the Punjab province, and covers an area of $3,016 \mathrm{~km}^{2}$ with population density of 903 persons $/ \mathrm{km}^{2}$. Sialkot soils belonged to four great groups, i.e., Haplustalf's (order; Alfisols), Ustochrepts (order; inceptisol), Ustofluvents (order; entisols), and Natrustalf's (order; Alfisols). Sialkot series (50\%; noncalcareous silt loam) was dominant with Gujranwala (20\%; non-calcareous silty clay loam) and Sialkot shallow phase (20\%; non-calcareous) being minor constituents. Remaining $10 \%$ include Pasrur series (non-calcareous silty clay), Shahdra (calcareous, stratified silt/sand loam), and Argan series (calcareous silt loam).

Preliminary survey was conducted to identify tannery units located in peri-urban areas of Sialkot city discharging effluents into the adjacent lands which are used for agricultural activities. Seventy-two tannery units were identified (Fig. 1), and soil samples were collected between October 5 and 21, 2009 from their periphery which received effluents actively throughout the year. From each site, triplicate surface soil samples were collected from depth of 3-10 cm within distance of $50 \mathrm{~m}$ from the point of discharge, including points where effluents appeared to have affected the relevant soils. Triplicate samples were composited and kept in labeled zip precleaned polythene bags. Each sample was air-dried, crushed, passed through 2-mm mesh sieve, and kept in prewashed metal-free glass containers at room temperature. Soil $\mathrm{pH}$, electrical conductivity (EC), TDS, and salinity were determined using 1:10 suspension of soil (w/v) in deionized water. Soil $\mathrm{pH}$ was determined by $\mathrm{pH}$ meter (Thermo Orien 240A); EC, TDS, and salinity were determined using combine meter (HI 8033). Alkalinity, chlorides, phosphates, and nitrate nitrogen were determined using standard procedures (APHA 1998). Organic matter (OM) was determined using Tyurin's method (Nikolskii 1963). 


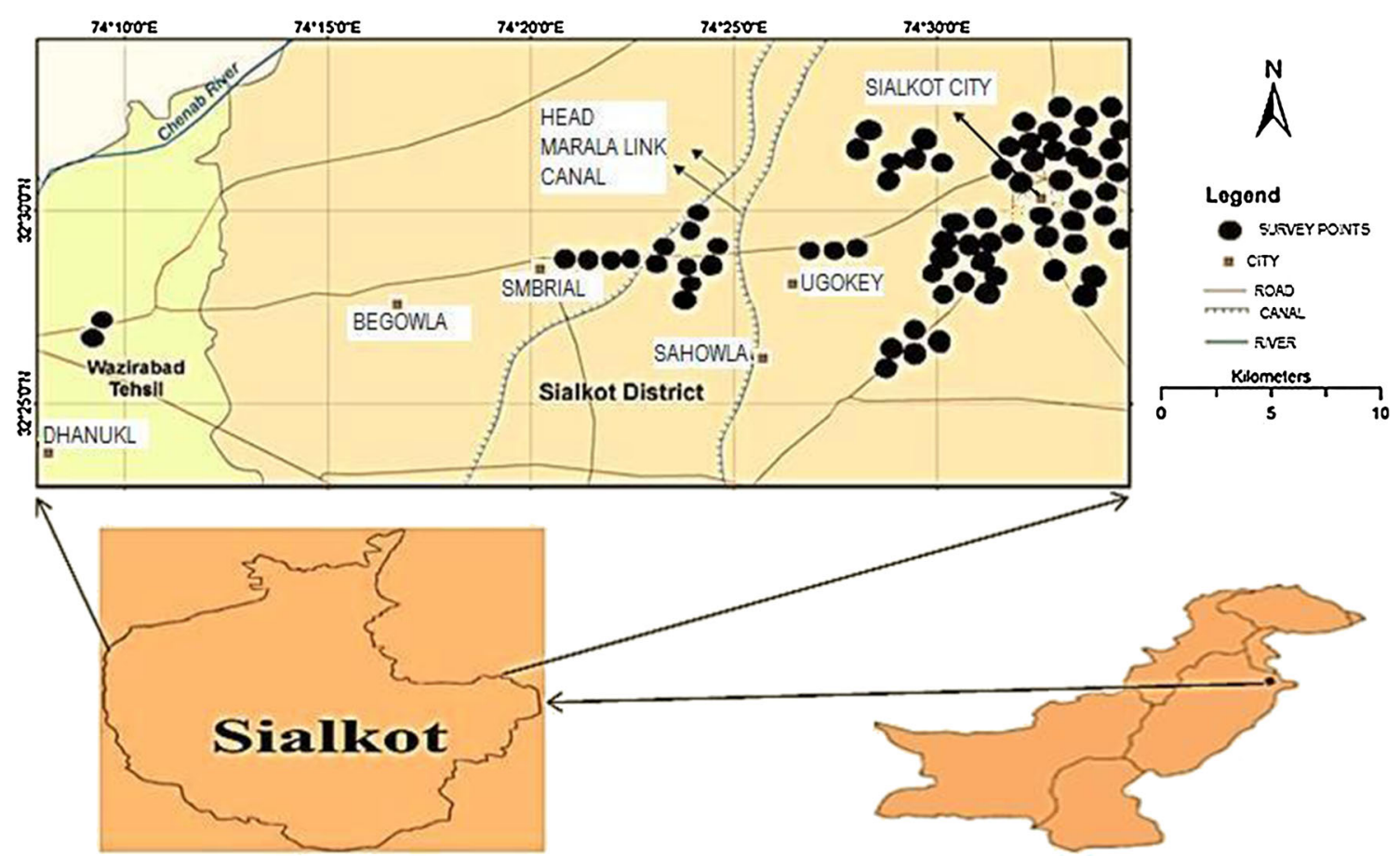

Fig. 1 Map of study area showing location of Tannery units (soil sampling points) in Sialkot district $(n=72)$

Heavy metal analysis and quality control/quality assurance (QC/QA)

For measurement of total metal concentrations, acid digests of each soil sample were prepared using USEPA method 3051A. Each soil sample measuring $0.5 \mathrm{~g}$ was placed in prewashed Teflon vessel and digested in microwaveaccelerated reaction system (MARS, CEM) at $220{ }^{\circ} \mathrm{C}$ for $15 \mathrm{~min}$ in the presence of $9 \mathrm{~mL}$ conc. $\mathrm{HNO}_{3}$ supplemented with $3 \mathrm{~mL}$ of conc. $\mathrm{HCl}$. Microwave unit was calibrated by ramping temperature to $220 \pm 5{ }^{\circ} \mathrm{C}$ and $1,200 \mathrm{~W}$ of power. Digested samples were filtered and diluted, and metal concentrations were determined in triplicate in air/acetylene flame using Fast Sequential Atomic Absorption Spectrophotometer (Model: AA240 FS by Varian, USA). The results of triplicate analyses were averaged and reanalyzed when relative standard deviation exceeded $5 \%$. Analytical blanks and standard reference material were prepared and run in the same way as soil samples, and heavy metal concentrations were determined using standard solutions prepared in the same acid matrix. Certified reference material CRM $320(N=3)$ of the Community Bureau of Reference (Belgium) was used to ensure the validation of data and accuracy/precision of analytical method. The recoveries were $84-101 \%$ for all metals. Metal concentrations were expressed in $\mathrm{mg} / \mathrm{kg}$ dry soil. Chemicals/ reagents used were of analytical grade. All glassware and plasticware used were soaked in $30 \% \mathrm{HNO}_{3}$ overnight, rinsed with deionized water before analysis.
Statistical analysis

Multivariate techniques such as factor analysis based on principal components (FA/PCA) were used to infer sources of metals either from natural or anthropogenic input. Varimax rotation was used to normalize principal component axes. Correlation matrix (CM) using Pearson coefficient was employed for relationship between heavy metals and other soil physiochemical parameters. Another multivariate technique Canonical correlation analysis (CCA) was used to analyze relationship between soil properties and metal concentrations. To account for changes in soil physicochemical properties in response to fluctuating total metal content, linear regression analysis was performed between soil parameters and total metal content expressed as MPI at each site. Cluster analysis was used to identify metal groups. Unweighted Pair-Group Average (median) was used as a linkage method and Pearson-r as a distance matrix. The statistical software package Statistica version 7.0 (Stat Soft Inc. USA) and Microsoft Excel, 2007 (Microsoft 2007) were used for all the statistical computations.

Quantification of metal pollution

Enrichment factor (EF) was calculated to determine anthropogenic input of metals in soils following Dantu (2009) using Eq. 1. Iron (Fe) was used for geochemical normalization and shale reference values were taken after Turekian and Wedepohl (1961). 
$\mathrm{EF}=\frac{\left(C_{i} / C_{\mathrm{Fe}}\right)_{\mathrm{s}}}{\left(C_{i} / C_{\mathrm{Fe}}\right)_{r}}$

where $\mathrm{EF}$ is enrichment factor of an element, $\left(C_{i} / C_{\mathrm{Fe}}\right)_{\mathrm{S}}$ is the ratio of the concentration of an element with that of iron at each sampling point, and $\left(C_{i} / \mathrm{C}_{\mathrm{Fe}}\right)_{r}$ is same ratio of the concentration with respect to reference soil. Soils were categorized into seven classes based on the value of EF: If $\mathrm{EF}<1$ no enrichment, $<3$ minor enrichment, 3-5 moderate enrichment, 5-10 moderate-to-severe enrichment, 10-25 severe enrichment, $26-50$ very severe enrichment, $>50$ extremely severe enrichment.

Enrichment factor percentage (EF \%) was calculated after Zonta et al. (1994) using Eq. 2:

$\mathrm{EF}(\%)=\frac{C-C_{\min }}{C_{\max }-C_{\min }} \times 100$

where $C=$ mean concentration of element in the soil, $C_{\max }=$ maximum concentration, while $C_{\min }=$ minimum concentrations measured in current study.

Geo-accumulation index $\left(I_{\mathrm{geo}}\right)$ was calculated after Muller (1979) using Eq. 3:

$I_{\text {geo }}=\log 2 \times \frac{C_{n}}{1.5 B_{n}}$

where $C_{n}=$ concentration of metal determined in the soil sample, $B_{n}=$ same metal's background concentration in the earth's crust adopted from Turekian and Wedepohl (1961), whereas 1.5 acts as a constant factor to neutralize variations due to lithogenic actions. Geo-accumulation index was described similar to that in the reference (Forstner et al. 1990).

In this study, $\mathrm{EF}, \mathrm{EF}(\%)$, and $I_{\text {geo }}$ were calculated for heavy metals excluding macro-nutrients.

Metal pollution index (MPI) was calculated to estimate total metal load at individual sites, following Usero et al. (2000) using Eq. 4:

$\mathrm{MPI}=(\mathrm{Cf} 1 \times \mathrm{Cf} 2 \times \mathrm{Cf} 3 \ldots \mathrm{Cf} n)^{1 / n}$

where $\mathrm{Cf}=$ concentration of metal in the sample.

Ecological risk assessment was performed using two risk indices viz. potential ecological risk index (RI) and pollution load index (PLI). Potential ecological risk index was developed after Hakanson (1980) for five toxic metals using Eqs. 5, 6, and 7:

$\mathrm{RI}=\sum_{i=1}^{m} E_{r}^{i}$

$E_{r}^{i}=T_{r}^{i} \times C_{f}^{i}$

$C_{f}^{i}=C_{s}^{i} / C_{n}^{i}$

where $C_{f}^{i}=$ contamination factor for ith metal; $C_{s}^{i}=i$ th metal concentration in the soil sample; $C_{n}^{i}=$ background concentration of ith metal taken from the uncontaminated soils due to the absence of background metal levels in the soils investigated (CEPA and CGSEM 1990); $T_{r}^{i}=$ toxic response factor suggested by Hakanson (1980) for five metals $\mathrm{Cd}$ (30), $\mathrm{Cr}$ (2), $\mathrm{Cu}$ (5), $\mathrm{Pb}(5), \mathrm{Zn}(1) ; E_{r}^{i}=$ potential ecological risk factor of individual metals; $\mathrm{RI}=$ potential ecological risk factor of multiple metals; $r=$ response factor in $T_{r}^{i}$ and risk factor in $E_{r}^{i} ; n=$ pristine or uncontaminated soils; $s=$ soil sample investigated; $i=$ any one of the above five metals. Modified standards for $C_{f}^{i}, E_{r}^{i}$, and RI classification criteria were adopted after Cao et al. (2007).

Pollution load index (PLI) was developed after Tomlinson et al. (1980) using Eq. 8 for comparison of pollution on different sites or at same site on temporal scale. Determination of PLI involves the calculation regarding concentration factor obtained by dividing the measured concentration of an element with the background concentration of the same element in shale (Turekian and Wedepohl 1961).

$\mathrm{PLI}=n \sqrt{\mathrm{CF} 1 \times \mathrm{CF} 2 \times \mathrm{CF} 3 \times \cdots \mathrm{CF} n}$

$\mathrm{CF}_{\text {metal }}=\frac{C_{\text {metal }}}{C_{\text {background }}}$

where $\mathrm{CF}=$ contamination factor; $n=$ number of metals; $C_{\text {metal }}$ and $C_{\text {background }}$ are the metal concentrations in the soil and background value of same element in the shale (Turekian and Wedepohl 1961).

\section{Results and discussion}

\section{Macro-nutrients ( $\mathrm{Na}, \mathrm{K}, \mathrm{Ca}$, and $\mathrm{Mg}$ )}

Basic statistical summary of studied metals is given in Table 1. Macro-nutrients were in the order: $\mathrm{Na}>\mathrm{Mg}>\mathrm{K}>\mathrm{Ca}$ with mean concentrations of 4,738, 2,925, 2,622 , and $1,902 \mathrm{mg} / \mathrm{kg}$, respectively. Macro-nutrients are essential for plant metabolism and generally not classified as dangerous elements. These nutrients constitute primary elements in parent rock material and are present in higher concentrations in upper horizons of earth core in associations with other metals. Their preferential accumulations in mobile forms (top $10 \mathrm{~cm}$ fraction) revealed that these can be readily transformed, liberating cations with slight change in $\mathrm{pH}$. Among the studied nutrients, none exceeded average shale values and remained at relatively lower concentrations. Elevated Na concentration can damage soil structure in certain soil types by limiting water movement and replacing $\mathrm{Ca} / \mathrm{Mg}$ ions affecting plant growth. Na levels $(1,782 \mathrm{mg} / \mathrm{kg})$ in our earlier study on urban soils of Sialkot were quite lower than present study due to substantial tanneries input (Malik et al. 2010). Mg becomes available 
Table 1 Basic statistical summary for the distribution of selected parameters in soil samples from Sialkot $(n=72)$

\begin{tabular}{|c|c|c|c|c|c|c|c|}
\hline S. no. & Parameters & Mean \pm SD & Min-max & $\mathrm{ASV}^{\mathrm{a}}$ & $\mathrm{BV}^{\mathrm{b}}$ & TEL/PEL ${ }^{\mathrm{c}}$ & ${\mathrm{ERL} / \mathrm{ERM}^{\mathrm{d}}}^{\mathrm{d}}$ \\
\hline 1 & $\mathrm{pH}$ & $8.2 \pm 1.2$ & $7.1-10.6$ & - & - & - & - \\
\hline 2 & $\mathrm{EC}(\mathrm{mS} / \mathrm{cm})$ & $4.6 \pm 5.3$ & $1.3-17.9$ & - & - & - & - \\
\hline 3 & TDS (mg/L) & $3,093 \pm 3,518$ & $800-11,700$ & - & - & - & - \\
\hline 4 & Salinity $(\mathrm{mg} / \mathrm{kg})$ & $10.3 \pm 15.6$ & $1.8-49$ & - & - & - & - \\
\hline 5 & Alkalinity (mg/kg) & $39,294 \pm 506$ & $600-18,990$ & - & - & - & - \\
\hline 6 & $\mathrm{Cl}^{1-}(\mathrm{mg} / \mathrm{kg})$ & $6,587 \pm 8,471$ & $282-24,088$ & - & - & - & - \\
\hline 7 & $\mathrm{PO}_{4}{ }^{3-}(\mathrm{mg} / \mathrm{kg})$ & $1.7 \pm 1.3$ & $0.3-5.20$ & - & - & - & - \\
\hline 8 & $\mathrm{NO}_{3}{ }^{1-}-\mathrm{N}(\mathrm{mg} / \mathrm{kg})$ & $301.3 \pm 743$ & $0.4-2,640$ & - & - & - & - \\
\hline 9 & $\mathrm{OM}(\%)$ & $1.3 \pm 0.8$ & $0.1-3$ & - & - & - & - \\
\hline 10 & $\mathrm{Cr}(\mathrm{mg} / \mathrm{kg})$ & $206 \pm 193$ & $21-675$ & 90 & 49.3 & $37.3 / 90$ & $80 / 145$ \\
\hline 11 & $\mathrm{Ni}(\mathrm{mg} / \mathrm{kg})$ & $6.4 \pm 4.4$ & $0.1-18$ & 68 & - & $18 / 36$ & $30 / 50$ \\
\hline 12 & $\mathrm{Mn}(\mathrm{mg} / \mathrm{kg})$ & $5.8 \pm 3.6$ & $0.1-11.7$ & 850 & - & - & - \\
\hline 13 & $\mathrm{Na}(\mathrm{mg} / \mathrm{kg})$ & $4,738 \pm 8,313$ & $307-29,626$ & 9,600 & - & - & - \\
\hline 14 & $\mathrm{~K}(\mathrm{mg} / \mathrm{kg})$ & $2,622 \pm 1,187$ & $765-4,789$ & 26,600 & - & - & - \\
\hline 15 & $\mathrm{Fe}(\mathrm{mg} / \mathrm{kg})$ & $44.4 \pm 29.2$ & $2.5-97$ & 47,200 & - & - & - \\
\hline 16 & Co $(\mathrm{mg} / \mathrm{kg})$ & $4 \pm 2.7$ & $0.01-5.3$ & 19 & - & - & - \\
\hline 17 & $\mathrm{Cu}(\mathrm{mg} / \mathrm{kg})$ & $4.2 \pm 3.3$ & $0.1-11.6$ & 45 & 26.7 & $35.7 / 197$ & $70 / 390$ \\
\hline 18 & $\mathrm{Ca}(\mathrm{mg} / \mathrm{kg})$ & $1,902 \pm 1,167$ & $305-4,986$ & 22,100 & - & - & - \\
\hline 19 & $\mathrm{Mg}(\mathrm{mg} / \mathrm{kg})$ & $2,925 \pm 2,117$ & $456-5,071$ & 15,000 & - & - & - \\
\hline 20 & $\mathrm{Zn}(\mathrm{mg} / \mathrm{kg})$ & $4.2 \pm 2.4$ & $0.5-8.7$ & 95 & 68.8 & $123 / 315$ & $120 / 270$ \\
\hline 21 & $\mathrm{Cd}(\mathrm{mg} / \mathrm{kg})$ & $0.7 \pm 0.6$ & $0.02-1.8$ & 0.3 & 0.12 & $0.60 / 3.53$ & $5 / 9$ \\
\hline 22 & $\mathrm{~Pb}(\mathrm{mg} / \mathrm{kg})$ & $3.4 \pm 1.5$ & $0.2-5.3$ & 20 & 19.4 & $35 / 91.3$ & $35 / 110$ \\
\hline
\end{tabular}

a Average shale values taken from Turekian and Wedepohl (1961)

b Background values taken from CEPA and CGSEM (1990)

c TEL/PEL values taken from Smith et al. (1996)

${ }^{\mathrm{d}}$ ERL/ERM values taken form Long and Morgan (1991)

to plants at higher $\mathrm{pH}$. Mean $\mathrm{pH}$ (8.2) coupled with elevated $\mathrm{Mg}$ levels can harm plant metabolic functions. Soil cation exchange capacity, and strong competitors like $\mathrm{K}$ can impair $\mathrm{Mg}$ availability to plants (Bermudez et al. 2010). No phytotoxicity is associated with $\mathrm{Ca}$ which acts as guard against $\mathrm{Cd}, \mathrm{Zn}, \mathrm{Pb}, \mathrm{Ni}$, and $\mathrm{Cu}$ pollution in surface soils. Ca increases solubility of $\mathrm{Na}, \mathrm{K}, \mathrm{NH}_{4}{ }^{1+}, \mathrm{Fe}^{2+}, \mathrm{Al}^{3+}$, and $\mathrm{Mg}$ as it competes for adsorption sites. Higher concentration of macro-nutrients in soil speeds up plant growth on uptake and favors heavy metal accumulation. In natural soils, these are mostly derived from geogenic sources; however, anthropogenic feedbacks from agrochemicals, organic fertilizers, solid manures, industrial effluents, and municipal wastes also contribute considerably. Soils being sink route metals to ground water, plants, and animals also referred as soil-water-plant-animal systems adversely affecting soil fertility, soil organisms, and humans through the food chain (McLaughlin et al. 2006).

Measured concentrations of $\mathrm{Ca}$ and $\mathrm{K}$ were higher than those reported in tannery-affected soils from Pakistan (Tariq et al. 2005, 2006, 2009) and India (Chandra et al.
2009). However, mean Na concentration was lower compared to those of tannery-affected soils from Peshawar $(12,912 \mathrm{mg} / \mathrm{kg})$ and Kasur $(18,765 \mathrm{mg} / \mathrm{kg})$ cities, Pakistan (Tariq et al. 2006, 2009). The results also indicated that measured $\mathrm{Mg}$ contents were the second highest from Pakistan after Peshawar (3,018 mg/kg; Tariq et al. 2006).

Heavy metals

Distribution of heavy metals in tannery-affected soils was in the order: $\mathrm{Cr}>\mathrm{Fe}>\mathrm{Ni}>\mathrm{Mn}>\mathrm{Cu}>\mathrm{Zn}>\mathrm{Co}>\mathrm{Pb}>\mathrm{Cd}$. Mean concentration of $\mathrm{Cr}(205.9 \mathrm{mg} / \mathrm{kg}), \mathrm{Ni}(6.4 \mathrm{mg} / \mathrm{kg}), \mathrm{Mn}$ $(5.8 \mathrm{mg} / \mathrm{kg}), \mathrm{Fe}(44.4 \mathrm{mg} / \mathrm{kg}), \mathrm{Cu}(4.2 \mathrm{mg} / \mathrm{kg}), \mathrm{Zn}(4.2 \mathrm{mg} /$ $\mathrm{kg})$, and $\mathrm{Cd}(0.7 \mathrm{mg} / \mathrm{kg})$ was higher to those found in tannery-affected soils from other parts of Pakistan (Tariq et al. 2005, 2006, 2009). However, measured concentrations of $\mathrm{Cr}, \mathrm{Mn}, \mathrm{Fe}, \mathrm{Cu}, \mathrm{Zn}, \mathrm{Cd}, \mathrm{Ni}$, and $\mathrm{Pb}$ were far lower to those reported in tannery-affected soils from the Uttar Pradesh, India (Chandra et al. 2009). Mean concentrations of $\mathrm{Ni}, \mathrm{Mn}, \mathrm{Pb}, \mathrm{Cu}, \mathrm{Zn}, \mathrm{Co}$, and $\mathrm{Fe}$ were well below to average shale values given in Turekian and Wedepohl 
(1961), whereas $\mathrm{Cu}, \mathrm{Zn}$, and $\mathrm{Pb}$ mean levels were less than background levels (Table 1). Similarly, mean concentration of $\mathrm{Ni}, \mathrm{Cu}, \mathrm{Zn}$, and $\mathrm{Pb}$ was well below to low range values, i.e., TEL's/ERL's, after Long and Morgan (1991) and Smith et al. (1996).

Mean $\mathrm{Cr}$ concentration $(206 \mathrm{mg} / \mathrm{kg})$ exceeded its average shale value $(90 \mathrm{mg} / \mathrm{kg})$, background value $(49.3 \mathrm{mg} /$ $\mathrm{kg}$ ), and maximum level (100 $\mathrm{mg} / \mathrm{kg}$ ) that may be present in soil (Chaney and Ryan 1993). Chromium is a less mobile element at neutral $\mathrm{pH}$, and its salts are used in un-hairing of hides in Pakistan (Qadir et al. 2008). $\mathrm{Cr}^{6+}$ adsorption decreases with increasing $\mathrm{pH}$, whereas, $\mathrm{Cr}^{3+}$ adsorption increases with increasing $\mathrm{pH}$ (Gowd et al. 2010). Owing to low solubility and mobility of $\mathrm{Cr}$, only small amount of $\mathrm{Cr}$ is bioavailable; therefore, in agricultural, soils treated with $\mathrm{Cr}$ bearing effluents/sludge, phytotoxicity is hardly observed (Alloway 1990). However, $\mathrm{Cr}$ is potentially toxic for agronomic plants at $0.5-5 \mathrm{mg} / \mathrm{L}$ in nutrient solution and $5-100 \mathrm{mg} / \mathrm{kg}$ in soils; therefore, its bioaccumulation can be fatally toxic to higher trophic levels. Chromium generates reactive oxygen species (ROS) in higher concentrations, which strongly interfere with biochemical processes. Mean $\mathrm{Cr}$ concentration exceeded TEL-PEL (threshold effect level-probable effect level) and ERL-ERM (effect range low-effect range median) values (Long and Morgan 1991; Smith et al. 1996).

Iron being an essential element is generally not considered hazardous metal pollutant, and its concentration ranged from $2.5-97 \mathrm{mg} / \mathrm{kg}$. At neutral to alkaline $\mathrm{pH}, \mathrm{Fe}$ is not known to cause toxicity. Measured $\mathrm{Cu}$ concentrations $(4.2 \mathrm{mg} / \mathrm{kg})$ were lower than soil environmental quality standards $(35 \mathrm{mg} / \mathrm{kg})$. It accumulates in surface soils from different anthropogenic sources (Kabata-Pendias 2004). In current study, its concentration in soils was mainly due to industrial and urban effluents. However, applications of agrochemicals can also be considered its possible source (Gowd et al. 2010). Hooda et al. (1997) determined heavy metals, i.e., $\mathrm{Ni}, \mathrm{Cu}, \mathrm{Zn}, \mathrm{Pb}$, and $\mathrm{Cd}$ toxicities from biosolid-amended soils and suggested that $\mathrm{Cd}, \mathrm{Ni}$, and $\mathrm{Zn}$ can pose greater hazard than $\mathrm{Cu} / \mathrm{Pb}$ on account of their bioaccumulation efficiency. Anthropogenic inputs of cobalt in agricultural soils include industrial effluents, traffic activities, and application of sewage sludge (Wei et al. 2010). Approximately, 33-44\% of Co occurs as stable organic complexes and is unavailable to aquatic or soil-dwelling organisms. Its bioavailability is essential for normal functioning of leguminous plants. In present investigation, mean Co levels $(4 \mathrm{mg} / \mathrm{kg}$ ) were far less than prescribed SQGs and possibly pose no threat to soil ecosystem.

Lead concentration ranged from $0.2-5.3 \mathrm{mg} / \mathrm{kg}$ and was within allowable levels, i.e., $15 \mathrm{mg} / \mathrm{kg}$ in soil (Chaney and Ryan 1993). Among trace metals, $\mathrm{Cd}$ is of particular interest as its concentration $(0.02-1.8 \mathrm{mg} / \mathrm{kg})$ in $40 \%$ soils was above permissible level in natural soils $(0.01-0.7 \mathrm{mg} /$ $\mathrm{kg}$ ). In such soils, acute Cd toxicity is expected which can harm production quality due to higher accumulation in edible portion of crops (McLaughlin et al. 2006). Industrial effluents especially tannery, motor vehicle exhaust, storage batteries, and agrochemicals can contribute to increased $\mathrm{Cd}$ levels in soils. Mean $\mathrm{Cd}$ concentration $(0.7 \mathrm{mg} / \mathrm{kg})$ exceeded its average concentration present in shale $(0.3 \mathrm{mg} / \mathrm{kg})$, background levels $(0.12 \mathrm{mg} / \mathrm{kg})$, and TEL $(0.6 \mathrm{mg} / \mathrm{kg})$; however, measured concentrations were lower to those of PEL (3.5 mg/kg) and ERL (5)/ERM (9) values (Long and Morgan 1991; Smith et al. 1996).

\section{Relationship between metals and other soil properties}

Most of the studied soils were basic in nature with $\mathrm{pH}$ ranging 7.1-10.6 and lower in $\mathrm{OM}$ that varied between 0.1 and $3 \%$. Soil $\mathrm{pH}$ positively correlated with alkalinity $(r=0.8), \mathrm{PO}_{4}{ }^{3-}(r=0.6)$, and $\mathrm{Mn}(r=0.7)$ (Table 2$)$. Soil pH indirectly/directly affects solubility, adsorption, retention, movement, and distribution of metals in surface soils (Equeenuddin et al. 2013). Manganese is a redoxsensitive element, which showed positive correlation with $\mathrm{pH}$. It is mobile particularly at lower $\mathrm{pH}$, while at basic $\mathrm{pH}$, it forms $\mathrm{Mn}(\mathrm{OH})_{4}$ that instantaneously traps substantial amounts of $\mathrm{Cd}, \mathrm{Co}, \mathrm{Pb}, \mathrm{Ni}$, and $\mathrm{Zn}$ by adsorption and coprecipitation (Braungardt et al. 2003). Mean concentration of $\mathrm{PO}_{4}{ }^{3-}$, alkalinity, $\mathrm{Cl}^{-1}$, and $\mathrm{NO}_{3}{ }^{1-}-\mathrm{N}$ was 1.7 , $3,929,6,587$, and $301 \mathrm{mg} / \mathrm{kg}$. TDS, salinity, OM, Cr, and Na showed significantly positive correlation $(r \geq 0.7)$ with EC and can be supported by the observation that tannery effluents generally increase soil salinity and sodicity decreasing crop production. Mean EC level $(4.6 \mathrm{mS} / \mathrm{cm})$ exceeds the salinity limit of $3 \mathrm{mS} / \mathrm{cm}$, rendering soils potentially unfit for salt-sensitive crops. Salinity also disturbs plant physiology by affecting plant-water status, nitrogen fixation, and ionic equilibrium. Significant correlation between $\mathrm{OM}$ and $\mathrm{EC}$ indicates strong affinities for cations/anions (Bermudez et al. 2010). Soil $\mathrm{Cl}^{-1}$ contents were positively correlated with metals, i.e., $\mathrm{Cr}(r=0.7)$, $\mathrm{Pb}(r=0.7)$, and $\mathrm{Na}(r=0.6)$ highlighting the use of their salts in leather-manufacturing process.

Measured OM contents were far lower than 5.8 and $7.8 \%$ reported from industrially affected soils (Bermudez et al. 2010). Accumulation of contaminants, salinization, and reduced OM levels may indicate chemical deterioration of soil ecosystems. Heavy metals accumulation affects soil characteristics, i.e., grain size, type and quantity of OM, CEC, soil biota, and mineral composition. Heavy metals in soils may inhibit activity of soil biota reducing the amount of OM incorporated into the soil system. Relatively lower mean OM $(1.3 \%)$ in studied soils can be 


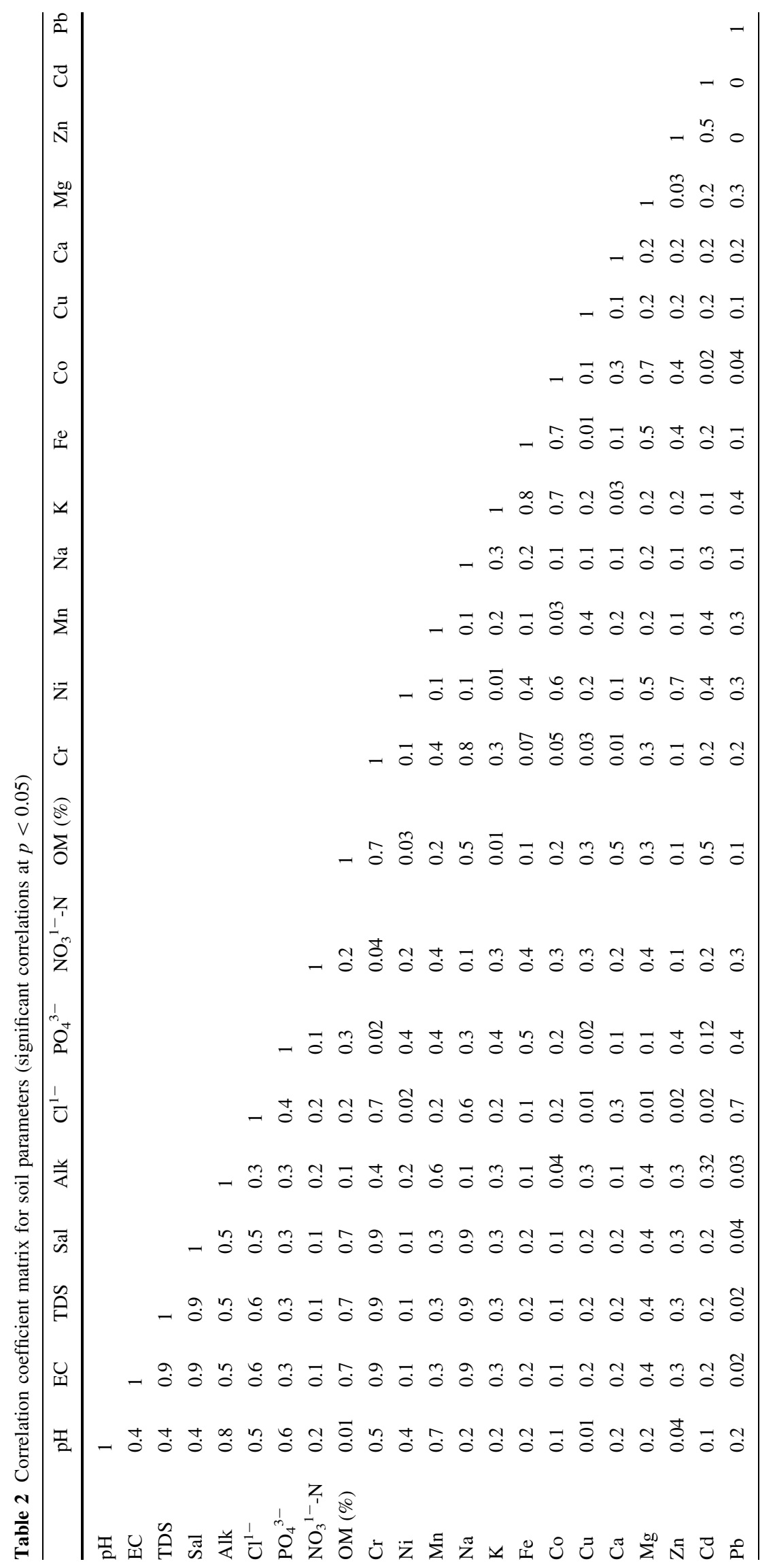


Table 3 Linear regression analysis of soil physicochemical parameters versus total metal content, i.e., MPI $(n=72) ; R^{2}$ is a regression coefficient

\begin{tabular}{ll}
\hline Regression equation & $R^{2}$ \\
\hline EC $=-5.091+0.26$ MPI & 48.6 \\
TDS $=-3,242+170.1$ MPI & 47.6 \\
Salinity $=-17.94+0.76$ MPI & 48.0 \\
OM $(\%)=-0.20+0.042$ MPI & 49.3 \\
\hline
\end{tabular}

attributed to high metal concentrations which may possibly be reduced/depleted soil fauna. As OM recycles nutrients, maintains water content, and helps in aeration, comparatively lower levels measured may alter soil processes and can damage soil ecosystem. According to Beyer (2001), if OM below $2.5-\mathrm{cm}$ soil layer is reduced significantly, then soil ecosystem may be considered as damaged; however, there exist few constraints regarding this approach. Standard soils generally contain $10 \%$ organic matter, and lowering of OM content can release OM-bound metal fractions increasing metal toxicity and bioavailability in soil. Greater level of salinity in studied soils can also limit OM's role as metal complex agent. This was obvious by positive correlation $(r=0.7)$ of $\mathrm{OM}$ with salinity, EC, TDS; and metals such as $\mathrm{Cr}(r=0.7), \mathrm{Na}(r=0.5)$, and $\mathrm{Ca}(r=0.5)$. Metals generally show affinities with organic matter (Bermudez et al. 2010). Chromium showed stronger affinities with OM with higher level of enrichment and accumulation and is highly toxic to biological organisms (Kabata-Pendias 2004). Relation of $\mathrm{Na}$ and $\mathrm{Ca}$ with OM \% was also described by Malik et al. (2010) in urban soils of Sialkot district with low OM contents which ranged from 0.04-0.7\%. Linear regression analysis revealed that soil properties viz. EC, TDS, salinity, and OM was considerably affected by soil metal content $\left(R^{2} \geq 48\right)$ (Table 3$)$. This relationship reflected significant changes in important soil physicochemical characteristics due to the accumulation of relatively higher metal content by various tanning related processes.

Canonical correlation analysis (CCA) predicted important correlations of soil physicochemical properties and metal concentrations. Soil physicochemical properties were represented by arrows and their respective length indicated importance of these variables in CCA (Fig. 2). First canonical axis was positively correlated with EC $(r=0.92)$, TDS $(r=0.92)$, salinity $(r=0.92)$, and OM \% $\quad(r=0.55)$ explaining $66.18 \%$ of variance (Table 4). The plane of the first canonical axis indicated $\mathrm{Na}$ and $\mathrm{Cr}$ being the dominant metals substantially impacting soil characteristics, i.e., EC, TDS, salinity, and OM \% in the investigated soils. Both metals originated in large quantities from salting and tanning of animal skins. Second canonical axis correlated positively with nitrates $(r=0.56)$ and was relatively less impacted by the metals, i.e., $\mathrm{Ca}$ and $\mathrm{K}$. Variance explained by second canonical axis was $11.66 \%$. Eigen values of the first two canonical axes were 0.34 and 0.06, respectively. Overall CCA results supported correlation and regression analysis results and showed changes in important soil properties due to higher metal built up in tannery adjacent soils.

Enrichment (EF/EF \%), geo-accumulation $\left(I_{\text {geo }}\right)$, and MPI results for heavy metals

Mean EF of heavy metals was in the order: $\mathrm{Cd}(8,598)>\mathrm{Cr}$ $(5,704)>\mathrm{Pb} \quad(652)>\mathrm{Ni} \quad(522.1)>\mathrm{Cu} \quad(283)>\mathrm{Co} \quad(245)>\mathrm{Zn}$ (92) $>$ Mn (25). Except for Mn which was severely enriched, all other metals showed extremely severe enrichment (Table 5). All soils with $\mathrm{Cr}$ and $>90 \%$ soils with $\mathrm{Cd}$ were extremely enriched ( $\mathrm{EF}$ values $>50)$. EF (\%) pointed substantial loading for $\mathrm{Cd}$ (37) contamination and comparatively lower for $\mathrm{Cr}$ (33) in studied soils. Lead showed extremely severe enrichment in $>84 \%$ of soils. About $77.8 \%$ of soils showed extremely severe enrichment with $\mathrm{Ni}$. However, mean $\mathrm{Ni}$ concentration $(6.4 \mathrm{mg} / \mathrm{kg})$ was well below to sediment quality guidelines $(\mathrm{mg} / \mathrm{kg})$, e.g., TEL/ PEL (18/36), ERL/ERM (30/50), and average Ni shale value, i.e., 68. Cobalt and $\mathrm{Cu}$ also showed extremely severe enrichment in $>70 \%$ of soils samples. In contrast, $\mathrm{Zn}$ showed extremely severe enrichment in $47 \%$ of soils. Manganese showed variations in enrichment patterns as compared to other metals. In contrast, $>69 \%$ of soils showed moderate to extremely severe enrichment for $\mathrm{Mn}$. Mean Mn concentration $(5.8 \mathrm{mg} / \mathrm{kg}$ ) was far lower than its concentration in shale $(850 \mathrm{mg} / \mathrm{kg})$. EF values discriminated between the metals originating from anthropogenic activities and those from natural origin or mixed sources of heavy metals.

Geo-accumulation index calculated background metal enrichment by comparing recent and preindustrial concentrations, though it was not easy to reach preindustrial soil/sediment layers. $I_{\text {geo }}$ classified all soils in unpolluted to moderately polluted $\left(I_{\text {geo }}\right.$ value $\left.=0-1\right)$ class with $\mathrm{Pb}$ and $\mathrm{Zn}$ (Table 5). Mean $I_{\text {geo }}$ values followed the order: $\mathrm{Cr}$ $(0.5)>\mathrm{Cd}(0.5)>\mathrm{Co}(0.04)>\mathrm{Pb}(0.03)>\mathrm{Ni}, \mathrm{Cu}(0.02)>\mathrm{Zn}$ (0.01) $>\mathrm{Mn}$ (0.001). $\mathrm{Mn}$ and $\mathrm{Zn}$ also indicated similar pattern of accumulation using mean $I_{\text {geo }}$ and mean EF values. Nearly, $24 \%$ soil with $\mathrm{Mn}$ and soil with Co showed $I_{\text {geo }}<0$ and grouped in unpolluted category, whereas the remaining soils for both metals qualified for unpolluted to moderately polluted group. For $\mathrm{Cd}$ and $\mathrm{Cr},>19 \%$ of soils were classified as moderately polluted conflicting with EF results $(\mathrm{EF}>50)$ which categorized nearly all soils extremely severe enriched with these metals. Geo-accumulation index classified all soils as unpolluted to 


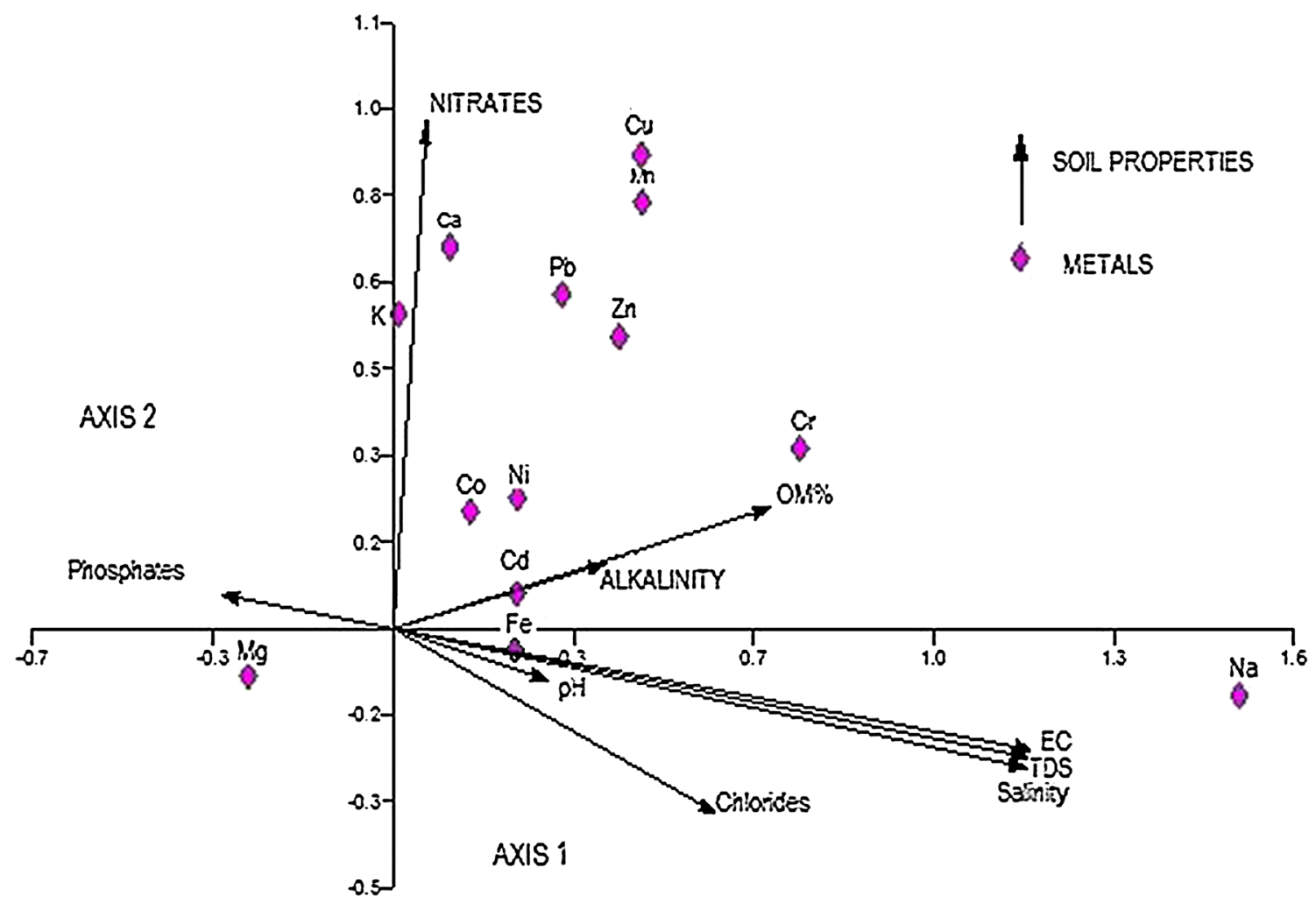

Fig. 2 Canonical correlation analysis (CCA) showing association between soil properties and metal concentrations

Table 4 Summary statistics of CCA

\begin{tabular}{lccc}
\hline Parameters & $\begin{array}{l}\text { Canonical } \\
\text { axis 1 }\end{array}$ & $\begin{array}{l}\text { Canonical } \\
\text { axis 2 }\end{array}$ & $\begin{array}{l}\text { Canonical } \\
\text { axis 3 }\end{array}$ \\
\hline Eigenvalues & 0.34 & 0.06 & 0.01 \\
Variance explained (\%) & 66.18 & 11.66 & 2.04 \\
Cumulative (\%) & 66.18 & 77.84 & 79.88 \\
pH & 0.22 & -0.06 & 0.01 \\
EC & $\underline{0.92}$ & -0.14 & -0.06 \\
TDS & $\underline{0.92}$ & -0.13 & -0.06 \\
Salinity & $\underline{0.92}$ & -0.15 & -0.03 \\
Alkalinity & 0.31 & 0.07 & 0.12 \\
Chlorides & 0.47 & -0.20 & -0.23 \\
Phosphates & -0.25 & 0.04 & -0.15 \\
Nitrates & 0.05 & $\underline{0.56}$ & -0.09 \\
OM (\%) & $\underline{0.55}$ & 0.13 & 0.21 \\
\hline
\end{tabular}

Significant correlation values are highlighted in italics with underlined at $p<0.05$

moderately polluted class $\left(I_{\text {geo }}\right.$ value $\left.=0-1\right)$ with $\mathrm{Cu}$. $I_{\text {geo }}$ result for $\mathrm{Cu}$ differed significantly from $\mathrm{EF}$ results which showed its extremely severe enrichment in $67 \%$ soils. In contrary based on $I_{\text {geo }}$, soils were classified in unpolluted to moderately polluted category with $\mathrm{Ni}$, and based on $\mathrm{EF}$, $18 \%$ soils showed very severe and $76 \%$ as extremely severe enrichment. Metal pollution index (MPI) values ranged from 18.7-67.9, indicating relatively higher contamination levels. Soils with MPI $\leq 1$ were classified as unpolluted, but in general, its class definition is biased, and there exists no threshold classification from unpolluted to highly polluted categories. Mean MPI value (36) suggested moderately high metal burden in investigated soils and $72 \%$ soils had MPI value $>30$.

Heavy metal risk assessment and impacts on adjacent ecological compartments

Table 5 represents ecological risk factor for individual metals $\left(E_{r}^{i}\right)$. The results showed that $\mathrm{Cd}(167)$ poses greater potential ecological risk followed by $\mathrm{Cr}(10), \mathrm{Pb}(0.8), \mathrm{Cu}$ (0.8), and $\mathrm{Zn}(0.1)$ reflected by their $E_{r}^{i}$ values. Cadmium has no biological function and is highly toxic to living organism (Alloway 1990). Toxic response factor $\left(T_{r}^{i}\right)$ for $\mathrm{Cd}$ was high (30) as compared to $T_{r}^{i}$ of $\mathrm{Cr}, \mathrm{Cu}, \mathrm{Zn}$, and $\mathrm{Pb}$ which along with relatively low background value $(0.12)$ is responsible for high $\mathrm{Cd} E_{r}^{i}$ (Wei et al. 2010; CEPA and CGSEM 1990). Potential ecological risk factor for multimetal (RI) represents the sensitivity of various biological communities to toxic heavy metals. RI classified examined soils in four risk categories, i.e., $54 \%$ soil were considered at low risk, $14 \%$ at moderate, $8 \%$ at high risk, and $25 \%$ soils at significantly high-risk categories. 
Table 5 Heavy metals enrichment, geo-accumulation, and risk assessment results in tannery-affected soils

\begin{tabular}{|c|c|c|c|c|c|c|c|c|}
\hline & $\mathrm{Cr}$ & $\mathrm{Cu}$ & $\mathrm{Zn}$ & $\mathrm{Cd}$ & $\mathrm{Pb}$ & $\mathrm{Ni}$ & $\mathrm{Mn}$ & Co \\
\hline EF min & 186 & 1.3 & 10.2 & 34.1 & 15.3 & 1.1 & 0.5 & 3.6 \\
\hline $\mathrm{EF} \max$ & 20,643 & 1,374 & 358 & 66,521 & 5,041 & 4,998 & 160 & 985 \\
\hline EF mean & 5,704 & 283 & 92 & 8,598 & 652 & 522 & 25 & 245 \\
\hline $\mathrm{EF}(\%)$ & 33 & 35 & 45 & 37 & 57 & 36 & 49 & 45 \\
\hline$I_{\mathrm{geo}} \min$ & 0.05 & 0.001 & 0.001 & 0.01 & 0.01 & 0.01 & 0 & 0 \\
\hline$I_{\text {geo }} \max$ & 1.5 & 0.05 & 0.02 & 1.2 & 0.05 & 0.1 & 0.003 & 0.09 \\
\hline$I_{\mathrm{geo}}$ mean & 0.5 & 0.02 & 0.01 & 0.5 & 0.03 & 0.02 & 0.0013 & 0.04 \\
\hline$C_{f}^{i}$ Min & 0.4 & 0 & 0.01 & 0.2 & 0.02 & - & - & - \\
\hline$C_{f}^{i} \max$ & 13 & 0.4 & 0.13 & 14.2 & 0.3 & - & - & - \\
\hline$C_{f}^{i}$ mean & 4.9 & 0.2 & 0.1 & 5.6 & 0.2 & - & - & - \\
\hline$E_{r}^{i} \min$ & 0.8 & 0.01 & 0.02 & 5.3 & 0.1 & - & - & - \\
\hline$E_{r}^{i} \max$ & 26 & 2.2 & 0.13 & 425 & 1.4 & - & - & - \\
\hline$E_{r}^{i}$ mean & 9.7 & 0.8 & 0.1 & 167 & 0.8 & - & - & - \\
\hline
\end{tabular}

Pollution load index (PLI) also categorized ecological risk and its values ranged from 0.1 to 0.2 . Mean PLI value $(0.1)$ recorded in this study was far lower than the threshold $(<1)$, indicating the absence of baseline pollutants or loads near to background levels (Tomlinson et al. 1980). Such low PLI values predicted that no drastic rectification measures are needed in the soils adjacent to tanneries; however, continued discharge of effluents can increase these values if waste and effluents coming from tanning industry are discharged without prior treatment. The results highlighted that ecological risk assessment approaches (e.g., $E_{r}^{i}$, RI, and PLI) can be used as a decision-support tools or instruments for prioritizing soil conservation and integrity assessment studies.

Heavy metals laden tannery effluents have not only impacted surface soils but also threatened underground aquifer, water channels, and aquatic diversity therein (Malik et al. 2010). Ground water is the sole irrigation and drinking source in Sialkot and facing considerable deterioration due to untreated disposal of tannery effluents. This scenario is particularly worse in and around the tannery hubs. Water channels, i.e., Nullah Palkhu and Nullah Aik (feeding tributaries of River Chenab), passing through the Sialkot district receive untreated tannery effluents in voluminous amounts which not only put local population at risk but also disturb the ecological integrity of these fresh waters (Qadir et al. 2008). In a study on eight edible species of fish found in these two streams described potential health risk for humans as their tissues metal contents were beyond permissible limits (Qadir and Malik 2011). Heavy metal inputs from tannery industries have a major proportion in contamination of these aquatic environments. In addition, waste water of Nullah Palkhu and Nullah Aik is used in vegetable and crops production in nearby areas, using electric pumps which pose potential exposure risk to soil-dwelling organisms, phytotoxicity, vulnerability of agricultural products through bioaccumulation, and human health hazards. Besides impacts on the environmental compartments, tannery workers are also at risk due to elevated metal concentrations used in tanning operations. This overall metal contamination intensity requires priority concerns for management of safe tannery effluents disposal strategies.

\section{Index comparison}

Two enrichment indices, i.e., EF, EF (\%), and accumulation index $\left(I_{\text {geo }}\right)$ were applied to evaluate metal status and their trends in surface soils. Among these, relative efficiency of EF and $\mathrm{EF}(\%)$ was better which presented fairly accurate and authentic picture of soils metal contents. $I_{\text {geo }}$ (background enrichment index) on the other hand did not predict actual metal accumulation levels and showed relatively very low level of metal accumulation contradicting EF and EF (\%) results. With few exceptions, $I_{\text {geo }}$ classified all soils as unpolluted to moderately polluted with heavy metals. For this reason, some authors (Abrahim and Parker 2008) criticized $I_{\text {geo }}$ application to determine pollution status of soils and proposed normalized values instead. According to Abrahim and Parker (2008), $I_{\text {geo }}$ factors are not freely comparable to other metal enrichment indices due to its calculation procedures. It involves background multiplication of 1.5 and a $\log$ function. The results obtained from $I_{\text {geo }}$ were therefore distinctly variable from enrichment indices (EF and $\mathrm{EF} \%$ ). The latter methods are, however, mostly related to tannery-affected soils. Equations used to determine geo-accumulation index (Eq. 3) and EF (Eq. 1) showed that final values are affected by the geochemical background levels (Dantu 2009). Differences produced in (enrichment and geo-accumulation) can also 
Table 6 Rotated factor loadings (varimax normalized) of all parameters in soil samples $(n=72)$ with marked loadings highlighted in italic and bold $p>0.7$ factor loadings of $\mathrm{PO}_{4}{ }^{3-}, \mathrm{NO}_{3}{ }^{1-}-\mathrm{N}, \mathrm{Cu}, \mathrm{Ca}$, $\mathrm{Mg}$, and $\mathrm{Cd}$ were $<0.7$ and not shown

\begin{tabular}{|c|c|c|c|c|c|}
\hline Parameters & VF 1 & VF 2 & VF 3 & VF 4 & VF 5 \\
\hline $\mathrm{pH}$ & 0.24 & 0.01 & 0.87 & 0.32 & 0.2 \\
\hline $\mathrm{EC}$ & 0.97 & 0.03 & 0.19 & 0.09 & 0.07 \\
\hline TDS & 0.97 & 0.03 & 0.21 & 0.08 & 0.09 \\
\hline Salinity & 0.97 & 0.08 & 0.2 & 0.05 & 0.02 \\
\hline Alkalinity & 0.29 & 0.1 & 0.85 & 0.05 & 0.13 \\
\hline $\mathrm{Cl}^{1-}$ & 0.5 & 0.13 & 0.19 & 0.78 & 0.02 \\
\hline $\mathrm{OM}(\%)$ & 0.76 & 0.2 & 0.15 & 0.31 & 0.07 \\
\hline $\mathrm{Cr}$ & 0.89 & 0.02 & 0.28 & 0.19 & 0.03 \\
\hline $\mathrm{Ni}$ & 0.09 & 0.29 & 0.34 & 0.12 & -0.78 \\
\hline $\mathrm{Mn}$ & 0.15 & 0.13 & 0.84 & 0.21 & 0.21 \\
\hline $\mathrm{Na}$ & 0.9 & 0.09 & 0.08 & 0.16 & 0.1 \\
\hline K & 0.24 & -0.83 & 0.24 & 0.33 & 0.12 \\
\hline $\mathrm{Fe}$ & 0.13 & 0.92 & 0.03 & 0.03 & 0.21 \\
\hline Co & 0.11 & 0.84 & 0.09 & 0.1 & 0.22 \\
\hline $\mathrm{Zn}$ & 0.21 & 0.34 & 0.04 & 0.03 & 0.75 \\
\hline $\mathrm{Pb}$ & 0.01 & 0.14 & 0.14 & -0.8 & 0.14 \\
\hline Eigenvalue & 6.51 & 3.83 & 2.91 & 2.53 & 2.15 \\
\hline $\begin{array}{l}\text { Total variance explained } \\
(\%)\end{array}$ & 29.6 & 17.41 & 13.23 & 11.49 & 9.77 \\
\hline
\end{tabular}

be attributed to the nature of their respective algorithms used since identical background values were applied in both type of indices. Enrichment and geo-accumulation indices results differed for most metals and, however, predicted similar enrichment patterns for $\mathrm{Cr}$ and $\mathrm{Cd}$. Highest $\mathrm{EF}(\mathrm{EF} \mathrm{Cd}=8,598, \mathrm{EF} \mathrm{Cr}=5,704)$ and similarly highest $I_{\text {geo }}$ values $\left(I_{\text {geo }} \mathrm{Cd}=0.5, I_{\text {geo }} \mathrm{Cr}=0.5\right)$ were scored by these two metals.

Metal pollution index and PLI classified soils in terms of total metal content present irrespective of toxicities of individual metals. For MPI, the greater the metal concentrations in individual soils the greater the MPI values, urging strong need for rectification measures. MPI did not compare total metal content with any value; therefore, it showed low performance score owing to comparability and sensitivity criteria. Moreover, this index is based on geometric averages and can be advantageous if compared with other aggregation techniques. The results of PLI were not promising, and PLI values for all soils remained very low $(<1)$ reflecting no need for soil remedial measures. However, soils were contaminated to varying degrees with heavy metals, and significant risk was associated with them. Hence, PLI did not prove useful and effective enough to extract meaningful information regarding metal pollution. Potential ecological risk index identified high risk $\left(E_{r}^{i}\right)$ associated with $\mathrm{Cd}(167)$ and $\mathrm{Cr}(10)$. Ecological risks posed by $\mathrm{Cd}$ and $\mathrm{Cr}$ in the soils of study area were also well accounted with enrichment and geo-accumulation indices along with two SQG's followed.

\section{Source identification}

FA/PCA for the soil parameters resulted in five variofactors (VFs) with eigenvalues $>2$ (Table 6; Fig. 3a, b). VF 1, 2, 3, 4 , and 5 accounted $29.6,17.4,13.2,11.5$, and $9.8 \%$ of total variance. Varimax factor 1 revealed significant loading for $\mathrm{EC}$, TDS, salinity, $\mathrm{OM} \%, \mathrm{Cr}$, and $\mathrm{Na}$ indicating input from tannery effluents. Correlation coefficient matrix also highlighted strong positive relationships. Chromium pollution is attributed to chrome plating, paint/pigments manufacturing, and leather tanning (Qadir et al. 2008). Tannery industry is the chief culprit for high $\mathrm{Cr}$ levels in surface soils of current study. VF2 loaded for $\mathrm{Co}, \mathrm{Fe}$, and $\mathrm{K}$ and their sources mainly related to parent rock material. However, these metals are also used in liming processes and may contribute toward soils contamination (Wei et al. 2010). VF3 showed highest loading for $\mathrm{pH}(r=0.87)$, indicating $\mathrm{pH}$ as one of the controlling factor for $\mathrm{Mn}$ availability. Solubility of $\mathrm{Mn}$ decreases at neutral to alkaline $\mathrm{pH}$, and it becomes unavailable to plants for normal growth and metabolism (Braungardt et al. 2003). Manganese is used in the form salts $\left[\mathrm{MnCO}_{3}\right.$ and $\left.\mathrm{Mn}\left(\mathrm{SO}_{4}\right)_{2}\right]$ in tannery industry (Tariq et al. 2006). This may be a possible reason for $\mathrm{Mn}$ and alkalinity relation; another explanation can be presence of rhodocrosite $\left(\mathrm{MnCO}_{3}\right)$ in soils, a natural mineral of Mn.

VF4 highlighted sources of $\mathrm{Pb}$ and $\mathrm{Cl}^{1-}$ from tannery effluents. Major sources of $\mathrm{Pb}$ in present soils include tannery effluents, automobiles exhaust fumes, paint/pigments manufacture, and less likely from atmospheric deposition. Its solubility in soil is principally controlled by its respective carbonates. Chloride's loading $(r=0.78)$ was second to $\mathrm{Pb}(r=-0.8)$, and its presence can be due to use of $\mathrm{NaCl}$ in tanning process. VF5 showed significant loadings for $\mathrm{Ni}(r=-0.78)$ and $\mathrm{Zn}(r=0.75)$, highlighting sources related to anthropogenic activities in particular to tannery effluents. Zinc is an essential trace element in living organisms whose higher concentrations are potentially toxic, but very insoluble and very rare in its nature (Alloway 1990). Mean $\mathrm{Zn}$ concentration found in this study was $4.15 \mathrm{mg} / \mathrm{kg}$, which is fairly low-tonormal threshold value set in agricultural soils, i.e., $200 \mathrm{mg} / \mathrm{kg}$. Relatively low levels of $\mathrm{Zn}$ in soil may be attributed to tannery effluents and usage of agrochemicals; however, to some extent, it can be lithogenic. Permissible range for $\mathrm{Ni}$ in natural soils in $\mathrm{mg} / \mathrm{kg}$ is $4.3-7$ compared to mean $\mathrm{Ni}$ concentration 6.4. Measured concentrations are within the safer limits; however, continuous discharge of untreated effluents may lead to higher concentrations in 
VF 1 vs. VF 2 vs. VF 3

Rotation: Varimax normalized

Extraction: Principal components

(a)

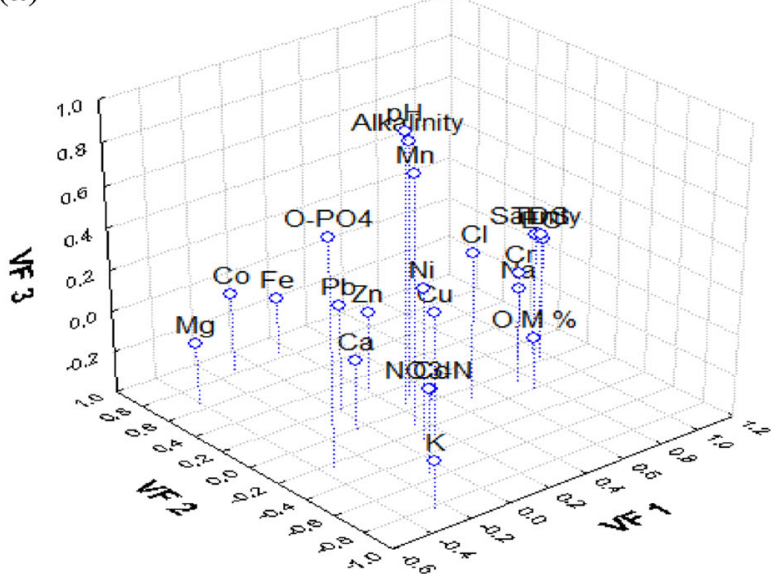

VF 3 vs. VF 4 vs. VF 5

Rotation: Varimax normalized

Extraction: Principal components

(b)

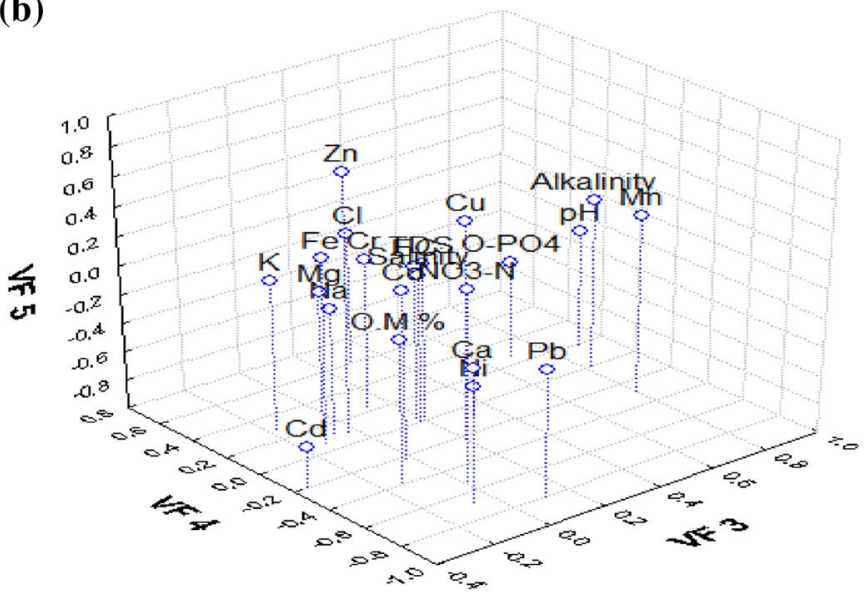

Fig. 3 a FA/PCA 3D scatterplot of first three variofactor loadings, b 3D scatterplot of VF 3 versus VF 4 versus VF 5

Fig. 4 Dendrogram of soil metals using UPGMA (Pearson-r)

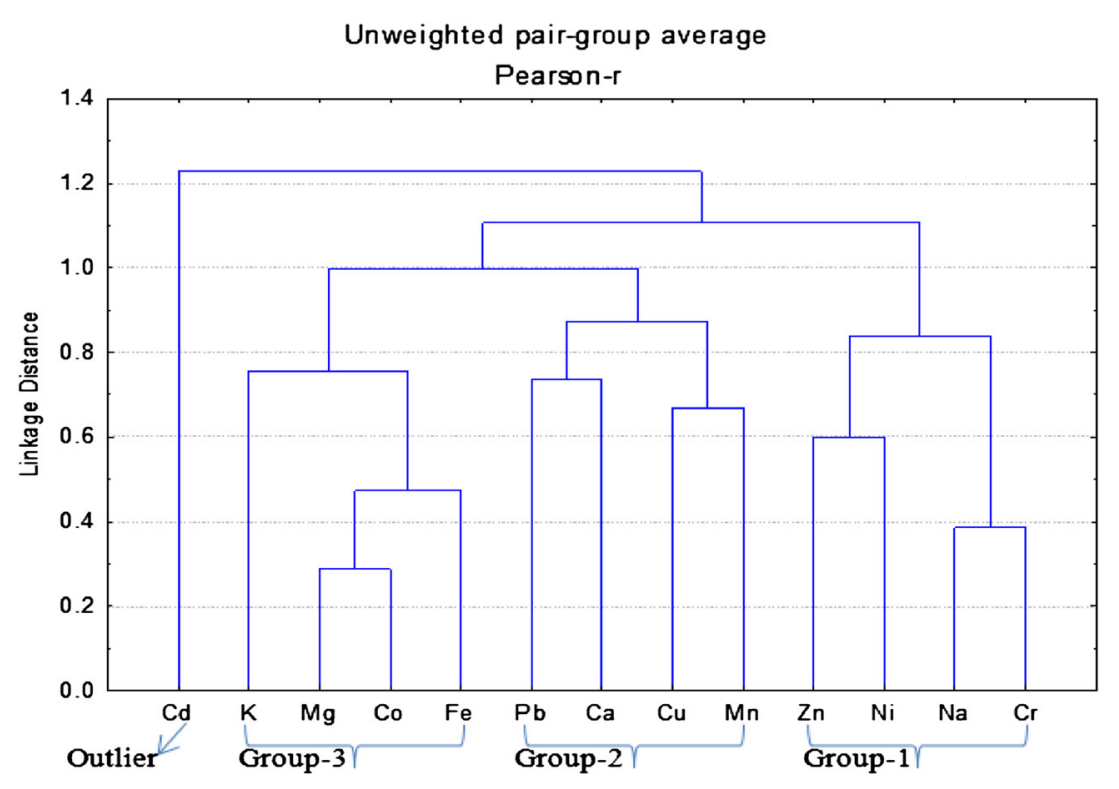

future. Presence of Ni can either be related to industrial effluents or with various metallurgical operations, burning of fossil fuels, and atmospheric deposition. Similarly, heavy metals such as $\mathrm{Cu}, \mathrm{Pb}, \mathrm{Zn}$, and $\mathrm{Ni}$ have also been linked to their use in various industrial processes in an earlier study by Qadir et al. (2008). Metal smelting, refining, agricultural and urban activities, and waste incineration are common in study area and can effectively contribute toward atmospheric input of heavy metals to the surface soils.

Cluster analysis identified three main groups of metals strengthening metals interrelationship as identified by FA/ PCA and correlation analysis (Fig. 4). Identified metal groups were used in similar tanning batch processes and provided a mean for source apportionment in the soil media. The resultant metal groups/clusters showed high intra-cluster homogeneity with origin in similar tannery operations. First group included metals, i.e., $\mathrm{Cr}, \mathrm{Na}, \mathrm{Ni}$, and $\mathrm{Zn}$ which were extensively employed in preservation, disinfection, and un-hairing processes of hides. Second group consisted of $\mathrm{Pb}, \mathrm{Mn}, \mathrm{Cu}$, and $\mathrm{Ca}$ used in retaining processes (post-tanning operations). Third group comprised of $\mathrm{Fe}, \mathrm{Co}, \mathrm{Mg}$, and $\mathrm{K}, \mathrm{Cd}$ being the outlier. These metals were employed in skin/hide treatment and liming/de-liming processes. Other than tannery input, 3rd group sources were also related to parent rock material. Soil metal clustering and their origin in related tanning operations evidenced soil contamination via tannery effluents. 


\section{Conclusion}

The impact of tannery industries on adjacent surface soils in terms of heavy metal enrichment, source apportionment, and associated risk was determined. Measured concentrations of macro-nutrients, i.e., $\mathrm{Ca}, \mathrm{K}$, and heavy metals, i.e., $\mathrm{Cr}, \mathrm{Ni}, \mathrm{Mn}, \mathrm{Fe}, \mathrm{Cu}, \mathrm{Zn}$, and $\mathrm{Cd}$ were higher in comparison with earlier studies conducted on tannery-affected soils from other parts of Pakistan. Soils were extremely enriched with $\mathrm{Cd}, \mathrm{Cr}, \mathrm{Pb}, \mathrm{Ni}, \mathrm{Cu}, \mathrm{Co}$, and $\mathrm{Zn}$. The results obtained from geo-accumulation index $\left(I_{\text {geo }}\right)$ were distinctly variable from $\mathrm{EF}$ and $\mathrm{EF}(\%)$. Only $\mathrm{Cd}$ and $\mathrm{Cr}$ ( $>19 \%$ soils) showed moderate pollution $\left(I_{\text {geo }}\right.$ value $\left.=1-2\right)$, and other heavy metals showed uncontaminated to moderately polluted soils $\left(I_{\text {geo }}\right.$ value $\left.=0-1\right)$ contradicting the results of $\mathrm{EF} / \mathrm{EF}(\%)$. $\mathrm{EF}$ and $\mathrm{EF}(\%)$ are more relevant for the evaluation of metal pollution related with tannery adjacent surface soils as compared to $I_{\text {geo }}$. Among pollution load (ecological risk index) and metal pollution index (contamination index), former index results were not satisfactory in interpreting risk associated with total metal content at individual sites, whereas later provided important information that can be used to plan remedial measures. PLI values for surface soils were low $(<1)$, suggesting the soils were unpolluted; however, MPI values ranged from 19-68 above threshold $\leq 1$ depicting metal contamination from low-to-high degree. Potential ecological risk index determined high risk associated with $\mathrm{Cd}$ and Cr. SQG's also highlighted $\mathrm{Cd}$ and $\mathrm{Cr}$ risk in tannery adjacent soils. Applied indices offered valuable information as long as their limitations are recognized. Multivariate analysis identified metals, i.e., $\mathrm{Cr}, \mathrm{Co}, \mathrm{Zn}, \mathrm{Pb}, \mathrm{Na}, \mathrm{Cd}, \mathrm{Fe}, \mathrm{Mn}$, and $\mathrm{Ni}$ originating from tannery input to surrounding soils. Source apportioning of metals in surface soils can help decision-makers to initiate management plans to reduce soil contamination. Substantial information extracted on elevated metal levels in tannery adjacent surface soils of Sialkot urges regulatory procedures for soil reclamation by available techniques.

Acknowledgments We are thankful to the reviewers for their constructive comments and valuable suggestions, which greatly improved the manuscript's quality. We also gratefully acknowledge the Faculty of Biological Sciences for provision of metal analysis facilities and Pakistan Wetlands Programme for transport facility.

\section{References}

Abrahim GMS, Parker RJ (2008) Assessment of heavy metal enrichment factors and the degree of contamination in marine sediments from Tamaki Estuary Auckland New Zealand. Environ Monit Assess 136:227-238

Alloway BJ (1990) Heavy metals in soils. Wiley, New York

APHA (1998) Standard methods for water and wastewater examination, 20th edn. American Public Health Association, Washington
Bermudez GMA, Moreno M, Invernizzi R, Plá R, Pignata ML (2010) Heavy metal pollution in topsoils near a cement plant: the role of organic matter and distance to the source to predict total and $\mathrm{HCl}-$ extracted heavy metal concentrations. Chemosphere 78:375-381

Beyer WN (2001) Estimating toxic damage to soil ecosystems from soil organic matter profiles. Ecotoxicology 10:273-283

Braungardt CB, Achterberg EP, Elbaz-Poulichet F, Morley NH (2003) Metal geochemistry in a mine-polluted estuarine system in Spain. Appl Geochem 18:1757-1771

Cao HC, Luan ZQ, Wang JD, Zhang XL (2007) Potential ecological risk of cadmium lead and arsenic in agricultural black soil in Jilin province China. Stoch Environ Res Risk Assess 23:57-64

Chandra R, Bharagavaa RN, Yadava S, Mohan D (2009) Accumulation and distribution of toxic metals in wheat (Triticum aestivum L) and Indian mustard (Brassica campestris L.) irrigated with distillery and tannery effluents. J Hazard Mater 162:1514-1521

Chaney RL, Ryan JA (1993) Heavy metal and toxic organic pollutants in MSW composts: research results on phytoavailabilty bioavailability etc. In: Hoitink HAJ, Keener HM (eds) Science and engineering of composting: design environmental. Microbiological and Utilization Aspects Renaissance Publications, Washington, pp 451-506

Chinese Environmental Protection Agency and Chinese General Station of Environmental Monitoring (CEPA and CGSEM) (1990) Soil chemical element background values of China. Chinese Environmental Science Press, Beijing (in Chinese)

Dantu S (2009) Heavy metals concentration in soils of southeastern part of Ranga Reddy district Andhra Pradesh India. Environ Monit Assess 149:213-222

Equeenuddin SKMD, Tripathy S, Sahoo PK, Panigrahi MK (2013) Metal behavior in sediment associated with acid mine drainage stream: role of $\mathrm{pH}$. J Geochem Explor 124:230-237

Forstner U, Ahlf W, Calmano W, Kersten M (1990) Sediments criteria development-contributions from environmental geochemistry to water quality management sediments and environmental geochemistry: selected aspects and case histories. Springer, Berlin, pp 311-338

Gowd SS, Reddy MR, Govil PK (2010) Assessment of heavy metal contamination in soils at Jajmau (Kanpur) and Unnao industrial areas of the Ganga Plain Uttar Pradesh India. J Hazard Mater 174:113-121

Hakanson L (1980) An ecological risk index for aquatic pollution control; a sedimentological approach. Water Res 14:975-1001

Hooda PS, Mcnulty D, Alloway BJ, Aitken MN (1997) Plant availability of heavy metals in soils previously amended with heavy applications of sewage sludge. J Food Agric 73:446-454

Kabata-Pendias A (2004) Soil-plant transfer of heavy metals-an environmental issue. Geoderma 122:143-149

Long ER, Morgan LG (1991) The potential for biological effects of sediment-sorbed contaminants tested in the national status and trends program NOAA technical memorandum NOS OMA 52. National Oceanic and Atmospheric Administration, Seattle, p 175

Malik RN, Jadoon WA, Hussain SZ (2010) Metal contamination of surface soils of industrial city Sialkot Pakistan: a multivariate and GIS Approach. Environ Geochem Health 32:179-191

McLaughlin MJ, Whatmuff M, Warne M, Heemsbergen D, Barry G, Bell M, Nash D, Pritchard D (2006) A field investigation of solubility and food chain accumulation of biosolid-cadmium across diverse soil types. Environ Chem 3:428-432

Muller G (1979) Schwermetalle in den sedimenten des RheinsVeränderungen seitt 1971. Umschan 79:778-783 (in German with English abstract)

Nikolskii NN (1963) Practical soil science. Technical Services US Department Commerce, Washington DC, p 240 
Qadir A, Malik RN (2011) Heavy metals in eight edible fish species from two polluted tributaries (Aik and Palkhu) of the River Chenab, Pakistan. Biol Trace Elem Res 143:1524-1540

Qadir A, Malik RN, Husain SZ (2008) Spatio-temporal variations in water quality of Nullah Aik-tributary of the River Chenab Pakistan. Environ Monit Assess 140:43-59

Smith SL, MacDonald DD, Keenleyside KA, Ingersoll CG, Field J (1996) A preliminary evaluation of sediment quality assessment values for freshwater ecosystems. J Great Lakes Res 22:624-638

Tariq SR, Shah MH, Shaheen N, Khalique A, Manzoor S, Jaffar M (2005) Multivariate analysis of selected metals in tannery effluents and related soil. J Hazard Mater 122:17-22

Tariq SR, Shah MH, Shaheen N, Khalique A, Manzoor S, Jaffar M (2006) Multivariate analysis of trace metal level in tannery effluents in relation to soil and water: a case study from Peshawar Pakistan. J Environ Manag 79:20-29

Tariq SR, Shah MH, Shaheen N (2009) Comparative statistical analysis of chrome and vegetable tanning effluents and their effects on related soil. J Hazard Mater 169:285-290
Tomlinson DL, Wilson JG, Harris CR, Jeffrey DW (1980) Problems in the assessment of heavy metal levels in estuaries and the formation of a pollution index. Helgolaender Meeresuntersuchungen 33:566-575

Turekian KK, Wedepohl KH (1961) Distribution of the elements in some major units of the earth's crust. Bull Geol Soc Am 72:175-192

Usero J, Garcia A, Fraidias J (2000) Calidad de las aguas y sedimentos del Litoral Andaluz in: Junta de Andalicia Consejeria del Medio Ambiente Sevilla (Editorial): 164

Wei B, Jiang F, Li X, Mu S (2010) Heavy metal induced ecological risk in the city of Urumqi NW China. Environ Monit Assess 160:33-45

Zonta R, Zaggia L, Argrse E (1994) Heavy metal and grain size distributions in estuarine shallow water sediments of the Cona Marsh (Venice Lagoon Italy). Sci Total Environ 151:19-28 